\title{
PEMANFAATAN E-LEARNING DALAM UJI COBA PERSIAPAN UJIAN NASIONAL DI PKBM ANAK NEGRI PAKET B
}

\author{
Yudi Wiharto ${ }^{1}$, Mufti $^{2}$ \\ ${ }^{1}$ Universitas Budi Luhur. Email: yudi.wiharto@budiluhur.ac.id \\ 2Universitas Budi Luhur. Email: muftyhayat@gmail.com
}

\begin{abstract}
PKBM (Teaching and Learning Activity Center) Anak Negri in Ciledug organizes a Package B equivalent to a Junior High School which will take the Computer-Based National Examination (UNBK). Because in the PKBM Anak Negri there are no facilities for their students to do computer-based exam training because that is a problem for the Negri Children PKBM. Therefore, we provide a solution for PKBM Anak Negri to provide Computer Based National Examination (UNBK) training by utilizing the Moodle e-learning application with 2 trials and 2 tests. It is expected that all participants who participate in this training can produce a satisfactory value.
\end{abstract}

Keywords: training, e-learning, PKBM, UNBK, moodle

\begin{abstract}
ABSTRAK
PKBM (Pusat Kegiatan Belajar Mengajar) Anak Negri di Ciledug menyelenggarakan Program Paket B setara SMP yang akan mengikuti Ujian Nasional Berbasis Komputer(UNBK). Karena pada PKBM Anak Negri belum ada fasilitas untuk peserta didiknya melakukan pelatihan ujian berbasis komputer karena itu menjadi permasalahan pihak PKBM Anak Negri. Maka dari itu kami memberikan solusi bagi PKBM Anak Negri untuk memberikan pelatihan Simulasi Ujian Nasional Berbasis Komputer (UNBK) dengan memanfaatkan aplikasi elearning Moodle dengan metode 2 kali test percobaan dan 2 kali test Ujian yang nantinya diharapkan semua peserta yang mengikuti pelatihan ini dapat menghasilkan nilai yang cukup memuaskan.
\end{abstract}

Kata Kunci: pelatihan, e-learning, PKBM, UNBK, moodle

\section{PENDAHULUAN}

Komputer termasuk salah satu media pembelajaran. Pengunaan komputer dalam pembelajaran merupakan aplikasi teknologi dalam pendidikan. Pada dasarnya teknologi dapat menunjang proses pencapaian tujuan pendidikan (Srimaya, 2017).

Implementasi dari pemanfaatan internet untuk pembelajaran salah satunya adalah e-learning. Pengertian sederhana dari e-learning adalah akses online kepada sumber belajar di mana saja dan kapan saja. E-learning menawarkan kesempatan baru kepada pengajar dan pembelajar untuk memperkaya pengalaman belajar mengajar melalui lingkungan maya (virtual) yang mendukung bukan hanya penyampaian materi namun juga penggalian dan aplikasi dari informasi serta pemahaman terhadap pengetahuan baru (Setiawan 2013). 
Moodle (Modular Object-Oriented Dynamic Learning Environment) merupakan perangkat lunak open source yang mendukung implementasi e-learning dengan paradigm terpadu dimana berbagai fitur penunjang pembelajaran dengan mudah dapat diakomodasi dalam suatu portal e-learning (Wulandari, 2015).

Saat ini banyak portal e-learning yang dikembangkan dengan perangkat lunak learning management system yang salah satunya moodle. Moodle merupakan perangkat lunak open source yang mendukung implementasi $e$-learning dengan paradigma terpadu di mana berbagai fitur penunjang pembelajaran dengan mudah dapat diakomodasi dalam suatu portal e-learning. Fitur-fitur penting penunjang pembelajaran tersebut misalnya tugas, kuis, komunikasi, kolaborasi, serta fitur utama yang dapat meng-upload berbagai format materi pembelajaran (Setiawan, 2013).

Pembelajaran di dalam kelas digital, sangat membantu para peserta didik untuk memahami pelajaran, pembelajaran menjadi lebih menyenangkan, memudahkan guru untuk menyampaikan materi pelajaran, mengevaluasi hasil belajar peserta didik sampai dengan memantau kehadiran peserta didik di kelas. Manfaat dari penggunaan IT di dalam pembelajaran akan terasa jika guru dapat menerapkannya di dalam kelas (Yuniarti, 2016).

Dalam mempersiapkan siswa PKBM (Pusat Kegiatan Belajar Mengajar) Anak Negri menghadapi Ujian Nasional Berbasis Komputer (UNBK) maka diperlukan sosialisasi bagi para siswa tersebut. Agar dapat berbagi sumber daya (resource sharing) dengan satuan pendidikan formal, maka jadwal Ujian Nasional Pendidikan Kesetaraan diatur agar dilaksanakan setelah UN (Ujian Nasional) di jenjang pendidikan formal selesai dilaksanakan. Selain itu, untuk meningkatkan pelaksanaan UNBK di jenjang pendidikan nonformal, pemerintah pusat (Kemendikbud) juga memberikan fasilitas unit komputer untuk PKBM dengan akreditasi A dan sudah memiliki gedung sendiri. Insentif berupa fasilitas komputer akan diberikan Kemendikbud secara bertahap untuk PKBM-PKBM terakreditasi A. Terkait peserta didik pendidikan nonformal yang berusia lanjut, diyakini bisa mengikuti UNBK dengan baik tanpa kesulitan menggunakan komputer. Dengan catatan mereka bisa menggunakan handphone (telepon seluler), pasti bisa UNBK (Kemdikbud n.d., 2018)

Berdasarkan uraian latar belakang di atas, beberapa permasalahan pokok yang dapat dirumuskan adalah sebagai berikut Bagaimana memotivasi warga belajar pada program pembelajaran yang dilaksanakan di PKBM Anak Negri menghadapi Ujian Nasional Berbasis Komputer? Bagaimana peran serta masyarakat dan warga sekitar terutama kampus Universitas Budi Luhur dalam mendukung keberlangsungan PKBM?

\section{METODE PELAKSANAAN}

Berdasarkan hal tersebut di atas, tim pengusul bermaksud memberikan pelatihan online dalam bentuk simulasi ujian online dengan soal-soal ujian yang sesuai Program Paket B setara SMP. Adapun materi-materi ujian adalah materi pelajaran yang di UN kan, seperti mata pelajaran Bahasa Indonesia, Bahasa Inggris, IPA (Ilmu Pengetahuan Alam) dan Matematika untuk SMP atau setara SMP. 
Tabel 1. Tahapan solusi

\begin{tabular}{lll}
\hline Tahap & Nama Tahapan & Solusi \\
\hline 1. & Pengajuan Surat Permohonan & $\begin{array}{l}\text { Penerimaan Surat Permohonan dan menyiapkan } \\
\text { materi pelatihan sesuai permohonan }\end{array}$ \\
\hline 2. & Jenis Pelatihan & $\begin{array}{l}\text { Pelatihan rekayasa Ujian Nasional Berbasis } \\
\text { Komputer menggunakan Moodle elearning }\end{array}$ \\
\hline 3. & Penentuan Lokasi Pelatihan & Laboratorium Universitas Budi Luhur Jakarta \\
\hline 4. & Jumlah Peserta & 32 peserta \\
\hline 5. & Lama Pelatihan & 1 Hari \\
\hline 6. & Monitoring & Pendampingan dalam mengerjakan rekayasa Ujian \\
& Nasional Berbasis Komputer selama pelatihan \\
& berlangsung. \\
\hline 7. & Evaluasi & Jumlah keberhasilan peserta pelatihan dalam \\
& mengerjakan soal-soal pelatihan dan kesiapan \\
& peserta dalam menggunakan Ujian Nasional \\
online.
\end{tabular}

Pada tahap awal pelaksanaan ini dilakukan beberapa aktivitas antara lain adalah pengumpulan data, dimana metode pengumpulan data dimaksudkan untuk mendapat informasi yang berhubungan dengan pelaksanaan kegiatan pengabdian ini agar tujuan yang akan dicapai dapat terpenuhi. Data tersebut diantaranya jumlah peserta pelatihan yang sudah atau belum mengenal dan menggunakan aplikasi komputer, data jumlah guru yang memiliki keterampilan terhadap penggunaan komputer. Selain itu juga dilakukan studi kepustakaan dengan mencari referensi untuk kebutuhan teoritis tentang kegiatan pengabdian masyarakat ini. Studi kepustakaan dilakukan dengan mencari buku-buku yang sesuai kebutuhan kegiatan pengabdian masyarakat, browsing melalui search engine, dan memanfaatkan perpustakaan Universitas Budi Luhur Jakarta untuk referensi teoritis. Dan juga dilakukan analisis kebutuhan terhadap kebutuhan-kebutuhan yang dapat menunjang penerapan kegiatan. Beberapa aspek analisis kebutuhan diantaranya lokasi, perlengkapan, bahan bacaan, peralatan penunjang teknologi informasi, keterampilan peserta pelatihan, keterampilan guru yang ada di PKBM Anak Negri. Tim pengusul melakukan kunjungan ke lokasi kegiatan sebagai bagian dari tahap pelaksanaan sehingga tim dapat mengetahui kondisi lapangan yang akan menjadi tempat pelaksanaan kegiatan. Tinjauan lokasi dapat dilakukan berulang kali untuk menjalin komunikasi interaktif terhadap mitra kegiatan. Pada pelaksanaan kegiatan, metode penyampaian materi secara langsung dengan peralatan pendukung, diskusi, kelompok, dan studi kasus, dapat membantu peserta lebih memahami materi pelatihan yang disampaikan. Lalu diakhiri dengan evaluasi terhadap jumlah keberhasilan peserta pelatihan dalam mengerjakan soal-soal pelatihan dan kesiapan peserta dalam melaksanakan Ujian Nasional online.

Adapun target luaran pada kegiatan pengabdian ini adalah Peserta pelatihan mampu mengerjakan soal-soal Ujian Nasional Berbasis Komputer yang di simulasikan menggunakan elearning moodle. Peserta pelatihan memiliki kemampuan untuk memanfaatkan komputer untuk mengerjakan Ujian Nasional yang akan mereka hadapi 
untuk tamat di PKBM dan mendapat ijazah setara SMP sesuai dengan program paket belajar yang diambil.

\section{HASIL DAN PEMBAHASAN}

Kegiatan ini dilaksanakan 1 (satu) hari yaitu pada hari Sabtu tanggal 13 April 2019 dari pukul 09.00 sampai dengan pukul 14.00 WIB. Peserta pelatihan yang hadir berjumlah 17 (tujuh belas) orang berasal dari siswa-siswi PKBM (Pusat Kegiatan Belajar Masyarakat) Anak Negri Ciledug, Tangerang. Lokasi penyelenggaraan bertempat di Lab ICT Universitas Budi Luhur, Jakarta. Pelaksanaan kegiatan pengabdian masyarakat ini dilakukan oleh tim terdiri dari 2 (dua) orang dengan pembahasan menyiapkan peserta pelatihan menghadapi Ujian Nasional Berbasis Komputer. Kegiatan yang diawali dengan pembukaan dan ramah tamah, kemudian dilanjutkan dengan materi pengenalan pembelajaran online menggunakan e-learning moodle dan menjelaskan cara menggunakan aplikasi tersebut. Tahapan kegiatan selanjutnya adalah Tryout Ujian Online menggunakan elearning moodle dengan 15 soal yang di acak sehingga tiap peserta akan berbeda soal. Tryout ini dilakukan sebanyak 2 kali percobaan. Setelah itu barulah dilakukan Simulasi Ujian Online dengan jumlah soal 50 soal campuran dari mata pelajaran yang diujikan pada Ujian Nasional yaitu mata pelajaran Matematika, Ilmu Pengetahuan Alam, Ilmu Pengetahuan Sosial, Bahasa Inggris dan Bahasa Indonesia.

Sebelum pelatihan dimulai, peserta pelatihan diberikan pertanyaan mengenai ujian online. Sebagian besar peserta sudah menguasai alat-alat teknologi sehingga nilai semua peserta pada pretest yang diberikan diberi nilai enam (6). Nilai ini diberikan dari evaluasi awal yang dilontarkan secara lisan kepada peserta pelatihan mengenai aspek penguasaan teknologi khususnya komputer. Sebagian besar peserta pelatihan mampu menggunakan komputer, membuka aplikasi e-learning, membuka menu di e-learning dan memberikan jawaban pada soal e-learning dengan meng-klik jawaban yang dipilih. Oleh karena itu, tim kegiatan pengabdian masyarakat memutuskan bahwa nilai setiap peserta sebelum diberi pelatihan rata-rata masih di grade 6 .

Dan peningkatan dari nilai post-test, maka dapat dikatakan bahwa pelatihan yang bertujuan untuk menyiapkan peserta pelatihan dalam menghadapi Ujian Nasional Berbasis Komputer di Laboratorium Universitas Budi Luhur mengalami perubahan yang berarti. Diharapkan dengan peningkatan pengetahuan ini peserta pelatihan dapat melakukan Ujian Nasional Berbasis Komputer berhasil baik dan memuaskan.

Kemudian tahapan berikutnya adalah melakukan try out ujian online dengan mengerjakan 15 (lima belas) soal campuran dari 5 (lima) mata pelajaran yang di ujikan di ujian nasional. Setelah istirahat beberapa menit, peserta pelatihan memulai simulasi ujian online berbasis komputer menggunakan elearning yang dilaksanakan dengan membagi 2 sesi, dimana sesi pertama simulasi ujian online berisikan 30 soal dengan gabungan mata pelajaran (Bhs. Indonesia, Bhs. Inggris dan IPS) setelah itu peserta istirahat kurang lebih 10 menit dan dilanjutkan dengan simulasi ujian online sesi kedua yang berisikan soal gabungan dengan mata pelajaran (IPA dan Matematika) sebanyak 20 soal.

Program kegiatan pengabdian masyarakat ini berupa simulasi ujian online dimana pelatihan ini untuk memperkenalkan dan mempersiapkan siswa siswi PKBM (Pusat 
Kegiatan Belajar Masayarakat) Anak Negri dalam menghadapi Ujian Nasional Berbasis Komputer yang sudah dilaksanakan ini diharapkan dapat menambah kepercayaan diri untuk menghilangkan kekakuan penggunaan teknologi dalam hal ini aplikasi komputer, sehingga siswa siswi PKBM Anak Negri dapat lebih siap dalam menghadapi Ujian Nasional Berbasis Komputer.

\section{SIMPULAN}

Target peserta pelatihan seperti direncanakan sebelumnya adalah sebanyak 30 (tiga puluh) orang peserta. Tapi dalam pelaksanaannya, kegiatan ini hanya diikuti oleh 17 (tujuh belas) orang peserta dikarenakan ada acara kunjungan dari Dinas diwaktu yang bersamaan dengan pelaksanaan ini. Dengan demikian dapat dikatakan bahwa target peserta tidak tercapai $100 \%$. Ketercapaian tujuan pelatihan mengacu pada hasil pre test dan post test menunjukkan hasil yang baik karena mengalami peningkatan. Sehingga dapat disimpulkan ketercapaian tujuan pelatihan sudah tercapai. Ketercapaian target materi yang telah direncanakan terlihat dari gambar hasil tryout dan gambar hasil ujian online yang menunjukkan peningkatan pencapaian dalam mengerjakan soal-soal ujian pada sesi tryout maupun pada sesi simulasi ujian online. Sehingga dapat disimpulkan ketercapaian target materi telah tercapai.

Dari beberapa peningkatan pencapaian tersebut dapat diambil kesimpulan bahwa kemampuan peserta dalam penguasaan materi mengalami peningkatan dan mendekati hasil sempurna dari yang diharapkan.

\section{DAFTAR RUJUKAN}

Setiawan, R., 2013. E-learning Moodle untuk meningkatkan motivasi dan hasil belajar teknologi informasi dan komunikasi tingkat SMP. Jurnal Ilmiah Guru "COPE”, No. 01/Tah. Available at: https://journal.uny.ac.id/index.php/cope/article/view/2955.

Srimaya, 2017. Efektivitas media pembelajaran power point untuk meningkatkan motivasi dan hasil belajar biologi siswa. Jurnal Biotek, Volume $5 \mathrm{~N}$. Available at: https://www.google.com/url?sa=t\&rct=j\&q=\&esrc=s\&source=web\&cd=1\&cad=rja \&uact=8\&ved=2ahUKEwi6x4zCnI_eAhXMwI8KHcrvD7QQFjAAegQICBAC\&url=http: //journal.uinalauddin.ac.id/index.php/biotek/article/download/3446/3241\&usg= A0vVaw09_DwEbsVWkxCDKi.

Yuliastuti, N., 2014. Pengembangan Media Pembelajaran IPA Terpadu Berbasis ELearning dengan Moodle Untuk Siswa Sekolah Menengah Pertama Pada Tema Pengelolahan Sampah. Jurnal Pendidikan Fisika, Vol.2.No.1.

Saifuddin, Much. Fuad. 2017. E-Learning Dalam Persepsi Mahasiswa. Varia Pendidikan, 29(2), 102-109.

Ciledug, R.B.A., 2012. Pusat Kegiatan Belajar Masyarakat. Available at: http://rsubhaktiasih.com/pkbm.php.

Kemdikbud, P. web, 97 Persen UN Pendidikan Kesetaraan Terapkan Berbasis Komputer. www.kemdikbud.go.id. 
https://www.kemdikbud.go.id/main/blog/2018/03/97-persen-un-pendidikankesetaraan-terapkan-berbasis-komputer.

Pendidikan, A.K.P.K.P.P., 2017. Kementerian Pendidikan Dan Kebudayaan Pusat Penilaian Pendidikan, Ujian Nasional Berbasis Komputer 2017/2018. web page. Available at: https://unbk.kemdikbud.go.id/tentang. 